\title{
Allele Frequency of Carbamazepine Major Efflux Transporter Encoding Gene ABCB1 C3435T among Javanese-Indonesian Population
}

\author{
Rochmy Istikharah ${ }^{1}$, Septiayu D. Hartienah ${ }^{2}$, Sandra Vitriyani ${ }^{2}$, Vitarani Dwi Ananda Ningrum ${ }^{3 *}$ \\ ${ }^{1}$ Department of Pharmacy, Laboratory of Biochemistry, Universitas Islam Indonesia, Yogyakarta, Indonesia; ${ }^{2}$ Department of \\ Pharmacy, Universitas Islam Indonesia, Yogyakarta, Indonesia; ${ }^{3}$ Department of Pharmacy, Laboratory of Pharmaceutical \\ Research, Universitas Islam Indonesia, Yogyakarta, Indonesia
}

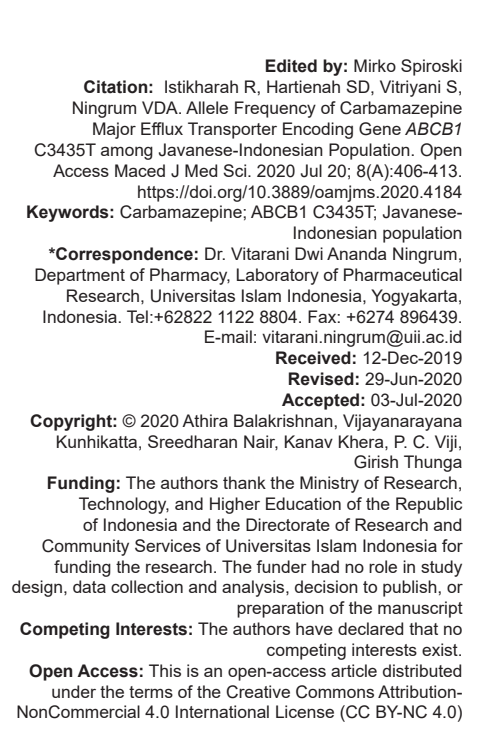

\section{Abstract}

BACKGROUND: Genetic variations in ABCB1 gene that encodes P-glycoprotein, the main transporter in the efflux of carbamazepine (CBZ) from the brain cells, can lead to pharmacodynamic and pharmacokinetic variability. Polymorphism of C3435T is widely known to cause protein overexpression that contributes to an increased risk of $\mathrm{CBZ}$ resistance.

AIM: This study determined the allele frequency distribution of ABCB1 C3435T gene in healthy subjects of the Javanese population as a major ethnic group in Indonesia.

METHODS: This cross-sectional study involved 100 healthy volunteers who fulfilled the inclusion criteria. The genotype analysis to detect polymorphism in the targets employed the polymerase chain reaction-restriction fragment length polymorphism method with 5'-TGCTGGTCCTGAAGTTGATCTGTGAAC-3' as the forward primer and 5'-ACATTAGGCAGTGACTCGATGAAGGCA-3' as the reverse primer.

RESULTS: The frequency of subjects with $\mathrm{C}$ allele in ABCB1 C3435T gene reached $53 \%$, higher than that with $\mathrm{T}$ allele.

CONCLUSION: This finding was nearly the same as that in studies of the populations in China, Turkey, and four countries in the South European continent. It is recommended to conduct further research on the correlation between C3435T polymorphism and CBZ dose variability to provide a comprehensive approach to epilepsy management in patients receiving $\mathrm{CBZ}$

\section{Introduction}

Epilepsy is the most prevalent chronic neurological disorder that affects at least 50 million people globally. It is characterized by periodic and unexpected seizures [1]. The prevalence in developing countries is higher than in developed countries; for example, the prevalence of epilepsy in Indonesia ranges between 5 and 74 per 1000 people. The best therapy in the management of epilepsy hitherto is using antiepileptic drugs (AEDs) [2].

Carbamazepine (CBZ) is a tricyclic compound used as the first-line AED for focal seizures, secondary generalized seizures, and tonic-clonic seizures [2]. CBZ is not only effective but also relatively inexpensive, making it listed in the AED monotherapy choices of the National Formulary since 2013 and available up to primary health-care facilities [3]. However, in addition to the risk of allergic reactions, CBZ is an AED with a narrow therapeutic range and often causes variations in pharmacokinetics and clinical response. Such variations occur due to polymorphism in the proteinencoding gene that plays a role in bioavailability and clinical response [4]. A number of pharmacogenetic studies of CBZ have been conducted to analyze genetic variants that strongly correlate with the variability of pharmacokinetics, clinical response, and adverse drug reactions (ADR). Regarding the polymorphism of HLA$B * 1502$ allele with the hazardous side effect named Stevens-Johnson Syndrome [5], research has been performed by involving the Indonesian population, with a frequency of mutant variant of $11.6 \%$ [6].

In addition to ADR risk, therapy failure due to $\mathrm{CBZ}$ resistance becomes another serious issue. It is estimated that approximately $30-40 \%$ epileptic patients experience $A E D$ resistance that leads to uncontrolled seizures despite the use of CBZ within the therapeutic 
dose range [7], [8]. Furthermore, the maintenance dose of epileptic patients in monotherapy reaches 10 -fold variety, indicating a wide interpatient variability of clinical response [9]. Among the contributing factors is the genetic polymorphism in the major CBZ efflux transporter named P-glycoprotein (P-gp) which is also expressed in the blood-brain barrier (BBB) [10]. Various studies have proved that the genetic variations in $A B C B 1$ C3435T gene as a P-gp encoder lead to $\mathrm{CBZ}$ resistance. A number of studies involving epileptic patients in Chinese, Japanese, and Caucasian populations found a positive correlation between such polymorphism and $\mathrm{CBZ}$ resistance or variations in $\mathrm{CBZ}$ plasma concentration [11], [12], [13]. Therefore, this study aims to determine the allele frequency distribution of $A B C B 1$ C3435T gene among the Javanese population, the largest ethnic group in Indonesia.

Pharmacogenetic understanding and studies of epilepsy therapy can provide important basic information for the development and implementation of genetic screening in making a decision on epilepsy therapy as well as become the basis for patient individualized medicine. This study is a section of prospective research on AED pharmacogenetics among the Indonesian population with epilepsy. Analysis of genetic variants in the target P-gp encoding gene is important to provide information on the genetic variation profile among the Indonesian population of which implications for individual therapeutic dose and clinical response to CBZ use can be further examined.

\section{Methods}

\section{Research subjects}

The DNA was extracted from $3 \mathrm{ml}$ blood of 100 healthy respondents aged 18-23 years. The category of respondents was those from Javanese ethnic group identified based on their three previous generations. This study has obtained ethical clearance from the Ethics Committee of the Faculty of Medicine of Universitas Islam Indonesia with the protocol No. 35/ Ka.Kom.Et/70/KE/XII.

\section{Genotyping}

Genotyping of $A B C B 1$ C3435T was conducted through the polymerase chain reaction (PCR) method using 5'-TGC TGG TCC TGA AGT TGA TCT GTG AAC-3' as the forward primer and 5'-ACA TTA GGC AGT GAC TCG ATG AAG GCA-3' as the reverse primer followed by restriction fragment length polymorphism. PCR conditions for amplification included initial denaturation at $95^{\circ} \mathrm{C}$ for $2 \mathrm{~min}, 35$ denaturation cycles at the same temperature for $30 \mathrm{~s}$, annealing at $55^{\circ} \mathrm{C}$ for $30 \mathrm{~s}$, extension at $72^{\circ} \mathrm{C}$ for $30 \mathrm{~s}$, and final extension at $72^{\circ} \mathrm{C}$ for $5 \mathrm{~min}$. The amplification products were visualized using agarose gel electrophoresis with $1.5 \%$ agarose concentration at 100 volts for $30 \mathrm{~min}$. The PCR products (248 bp) were digested using Mbol enzyme that identified and cut |GATC sequence in the amplicon. The digestion of amplification products yielded $16 \mathrm{bp}$, $60 \mathrm{bp}$, and $172 \mathrm{bp}$ fragments of CC genotype, $16 \mathrm{bp}$, $60 \mathrm{bp}, 172 \mathrm{bp}$, and $232 \mathrm{bp}$ of CT genotype, and $16 \mathrm{bp}$ and 232 bp of TT genotype.

The genotype and allele frequencies were determined based on the data of previous studies [11], [12], [13], [14] that used Hardy-Weinberg's law as follows [15], [16]:

$$
\text { Genotype frequencies }=\frac{\begin{array}{l}
\text { A givennumber of allelesin } \\
\text { thepopulation }
\end{array}}{\begin{array}{l}
\text { Totalnumber of alleles in } \\
\text { thepopulation }
\end{array}}
$$

Meanwhile, the allele frequencies were determined using the following formula:

$$
\begin{aligned}
& f(C)= \begin{array}{l}
(2 \times \text { Number of CCIndividuals })+ \\
(2 \times \text { TotalNumber of Individuals })
\end{array} \\
& f(T)=(2 \times \text { Number of TT Individuals })+ \\
&(2 \times \text { TotalNumber of Individuals })
\end{aligned}
$$$$
f(C) \text { : C allele frequency }
$$$$
\mathrm{f}(\mathrm{T}) \text { : } \mathrm{T} \text { allele frequency }
$$

\section{Results and Discussion}

A total of 100 healthy respondents of

\begin{tabular}{|c|c|c|}
\hline Patient characteristic & Male (50) & Female $(50)$ \\
\hline Average age (years) & $21.3 \pm 1.2$ & $21.1 \pm 1.4$ \\
\hline Average BMI $\left(\mathrm{kg} / \mathrm{m}^{2}\right)$ & $22.7 \pm 4.1$ & $21.5 \pm 3.4$ \\
\hline \multicolumn{3}{|c|}{ Types of $A B C B 1$ C3435T genotype } \\
\hline $\mathrm{CC}$ & 14 & 10 \\
\hline CT & 29 & 29 \\
\hline TT & 7 & 11 \\
\hline \multicolumn{3}{|c|}{ Types of $A B C B 1$ C3435T allele } \\
\hline C & 57 & 49 \\
\hline $\mathrm{T}$ & 43 & 51 \\
\hline
\end{tabular}
Javanese-Indonesian descent participated in the $A B C B 1$ C3435T gene genotyping with the same numbers of male and female respondents. The research subject characteristics are described in Table 1.

This study found that the frequencies of genotypic variation of both male and female respondents were insignificantly different. Although it is acknowledged 
that gender and genetic variation frequencies are not correlated, P-gp expression and function indicate gender variations at the molecular level [17]. Therefore, in a pharmacogenomic study targeting polymorphism in $A B C B 1$ genes that encode $\mathrm{P}$-gp protein, in addition to employing a prospective technique and adequate sample size [18], taking comorbidity factors into account, and using other drugs of P-gp inducer or inhibitor [19], and it is necessary to involve equal numbers of male and female patients to provide more accurate data analysis and results. Men and women have differences not only in P-gp expression and function but also in CBZ clearance, with even a significant difference level, in an infusion therapy [20].

Overall, the findings showed that the frequencies of CC, CT, and TT genetic variation in ABCB1 C3435T (rs1045642) were $24 \%, 58 \%$, and $18 \%$, respectively. Research with the same polymorphism targets as this study has been widely performed by involving a variety of populations and various races (Table 2.)

The electrophoretic display of enzyme digestion for the detection of target polymorphism in this study is shown in Figure 1.

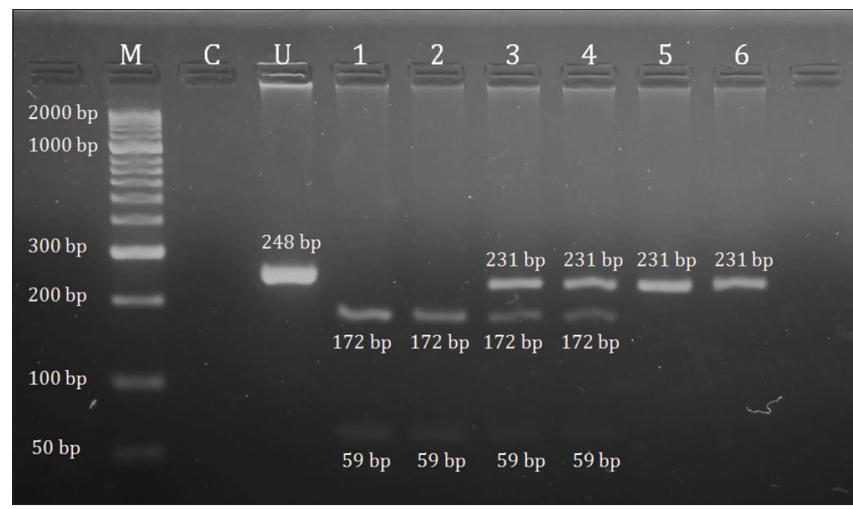

Figure 1: Electrophoretic display of genotypic variations in the target SNPs. Lane $M=$ marker of $50 \mathrm{bp}$; lane $C=$ negative control; lane $U=$ undigested; lane 1 and $2=C C$ homozygote/wild-type (172 bp and $59 \mathrm{bp})$; lane 3 and $4=C T$ heterozygote $(231 \mathrm{bp}, 172 \mathrm{bp}$, and $59 \mathrm{bp}$ ); lane 5 and $6=T T$ homozygote $(231 \mathrm{bp})$. SNPs: Single nucleotide polymorphisms

Numerous studies (Table 2) have linked genetic variations in $\mathrm{P}$-gp encoding gene $A B C B 1$ to mRNA stability variations [10], the risk of epilepsy, CBZ resistance, and therapeutic dose requirements. A study involving 738 subjects in South India showed that $A B C B 1$ C3435T increased the risk of mesial temporal lobe epilepsy with hippocampal sclerosis [31]. In addition, a study of 84 Chinese epileptic patients who received $C B Z$ monotherapy and 210 Chinese patients who received $C B Z$ for at least 1 month found that $A B C B 13435-T T$ had a lower CBZ plasma concentration, and the $A B C B 13435 C C$ group showed higher $C_{C D}$ (concentration: Dose ratio, i.e., the ratio of measured CBZ concentration to the daily maintenance dose in $\mathrm{mg} / \mathrm{kgBW}$ ) than the 3435CT type [13], [21]. Other studies of 315 epileptic patients at the National Hospital for Neurology and Neurosurgery in London as well as
210 Japanese patients with epilepsy who were given $\mathrm{CBZ}$ for more than 2 years indicated different risks of $C B Z$ resistance. The first study found that patients with CC genotype had a higher drug resistance compared to the group of TT genotype with 2.66 odds ratio (OR) and 1.32-5.38 confidence interval $(\mathrm{Cl})$ while the second study revealed that the TT genotype group was more prone to CBZ resistance instead (OR: 3.64, Cl: 1.1611.39) [11], [12]. Contradictory results were shown by two studies, each of which involved 97 epileptic patients with $\mathrm{CBZ}$ monotherapy and 174 healthy volunteers and 34 patients and 81 healthy subjects, in which no correlation was found between $A B C B 1$ C3435T and either CBZ resistance or clinical response to AED [14], [29]. These varied results of studies that involved different ethnic groups or races should consequently consider the study of $A B C B 1$ haplotype or diplotype that represents the functional unit of the gene [11]. Meanwhile, a systematic review and metaanalysis of 13 studies involving a total of 454 patients with AED-resistant epilepsy and 282 response-to-AEDs indicated that TT genotype of $A B C B 1$ C3435T played an important role in the incidence of refractory epilepsy [49].

The ATP-binding cassette transporter is widely known as the largest group of transmembrane transporters expressed in various tissue barriers including in the brain capillaries that construct the BBB, localized to the endothelial layer which can limit the entry of lipophilic drugs into the brain and express substances, such as $\beta$-amyloid, from neuroparenchyma. $\mathrm{P}$-gp pushes xenobiotics from the intracellular part back to the capillary lumen, thus maintaining BBB integrity and reducing drug accumulation in the cerebral region. Since P-gp transporter is highly expressed in BBB, the polymorphism in $A B C B 1$ gene as a P-gp encoder that influences the level of expression and function can directly affect the brain uptake as well as extrusion of AEDs, including CBZ. P-gp overexpression has been proven to play an important role in a pharmacoresistant incidence in epilepsy through decreased drug concentrations in the brain even though with a plasma therapeutic concentration [53].

Since P-gp is extensively expressed not only in $\mathrm{BBB}$ but also in various body tissues including in small intestine and large intestine, adrenal glands, liver, kidney, placenta, and capillary endothelial cells of testes, $\mathrm{P}$-gp also plays a role in the absorption, distribution, and excretion of numerous drugs as its substrates, and its function can be influenced by the presence of inhibitor drugs. Anumber of studies have also found the influence of the target polymorphism in this study on pharmacokinetic variations, clinical response, and risk factors of cancer. C3435T polymorphism has also been proven to cause variations in the concentrations, dose requirements, and clinical response of the drugs that function in the central nervous system, such as phenobarbital, opioids, and aripiprazole [22], [36], [44]. Similarly, some studies found a significant influence of such polymorphism on 
Table 2: Genotype frequencies of $A B C B 1$ C3435T in different ethnic populations

\begin{tabular}{|c|c|c|c|c|c|c|}
\hline \multirow[t]{2}{*}{ Population/ethnicity } & \multirow[t]{2}{*}{ Sample size } & \multicolumn{3}{|c|}{ Genotype frequencies n (\%) } & \multirow[t]{2}{*}{ Findings } & \multirow[t]{2}{*}{ References } \\
\hline & & $\mathrm{CC}$ & CT & TT & & \\
\hline \multicolumn{7}{|l|}{ Original article } \\
\hline Javanese, Indonesian & 100 & $24(24.00)$ & $58(58.00)$ & $18(18.00)$ & $\begin{array}{l}\text { The mutant allele frequency of } A B C B 1 \mathrm{C} 3435 \mathrm{~T}(47 \%) \text { was lower } \\
\text { than that of } \mathrm{C} \text { allele }\end{array}$ & The present study \\
\hline Chinese & 84 & $30(35.71)$ & $39(46.43)$ & $15(17.86)$ & $\begin{array}{l}\text { T allele was found at } 41.1 \% \text {. This allele correlated with the } \\
\text { decreased plasma concentration of CBZ in Chinese patients with } \\
\text { epilepsy }\end{array}$ & Meng et al. (2011) [13] \\
\hline Turkish & 97 & $29(29.90)$ & $55(56.70)$ & $13(13.40)$ & $\begin{array}{l}\text { T allele frequency reached } 41.8 \% \text {. There was no significant } \\
\text { correlation between MDR1 (C3435T) polymorphism and CBZ } \\
\text { resistance among patients with epilepsy in Turkey }\end{array}$ & Ozgon et al. (2008) [14] \\
\hline Japanese & 210 & $70(33.33)$ & $92(43.81)$ & $48(22.86)$ & $\begin{array}{l}\text { The mutant allele frequency of C } 3435 \mathrm{~T}(44.8 \%) \text { was lower compared } \\
\text { to that of } \mathrm{C} \text { allele. Epileptic patients with T allele and mutant TT } \\
\text { variant genotype were more likely to experience CBZ resistance }\end{array}$ & Seo et al. (2006) [11] \\
\hline Caucasian & 315 & $73(23.17)$ & $169(53.66)$ & $73(23.17)$ & $\begin{array}{l}\text { The frequency of } \mathrm{T} \text { allele was identical with that of } \mathrm{C} \text { allele in } \\
A B C B 1 \mathrm{C} 3435 \mathrm{~T} \text {. If compared to patients with antiepileptic drug } \\
\text { response, those with antiepileptic drug resistance had CC } \\
\text { genotype in } A B C B 13435 \text { as opposed to TT genotype }\end{array}$ & Siddiqui et al. (2003) [12] \\
\hline Chinese & 210 & $68(32.38)$ & $112(53.33)$ & $30(14.29)$ & $\begin{array}{l}\text { T allele frequency was } 41.0 \% \text {. The study found that } A B C B 1 \\
\text { c. } 3435 C>T \text { was significantly associated with the ratio of CBZ } \\
\text { concentration to dose from CBZ and its primary metabolites in } \\
\text { Chinese patients with epilepsy }\end{array}$ & Zhu et al. (2014) [21] \\
\hline Chinese & 112 & $45(40.18)$ & $49(43.75)$ & $18(16.07)$ & $\begin{array}{l}\text { The mutant allele frequency of C } 3435 T \text { ( } 37.9 \%) \text { was lower than } \\
\text { that of } C \text { allele. If cancer patients with TT genotype in } A B C B 1 \\
\text { suffered pain, they required a higher dose of opioid compared to } \\
\text { those with CC/CT type }\end{array}$ & Gong et al. (2013) [22] \\
\hline Han Chinese & 292 & $103(35.28)$ & $151(51.71)$ & $38(13.01)$ & $\begin{array}{l}\text { T allele frequency was found at } 38.9 \% \text {. The } A B C B 1 \text { rs } 1045642 \\
\text { gene did not correlate with the therapeutic response of } \\
\text { antidepressants (both selective serotonin reuptake inhibitors and } \\
\text { serotonin-norepinephrine reuptake inhibitors) in Han Chinese } \\
\text { patients with depression }\end{array}$ & Shan et al. (2019) [23] \\
\hline Han Chinese & 185 & $74(40.00)$ & $82(44.32)$ & $29(15.68)$ & $\begin{array}{l}\text { T allele was } 37.8 \% \text {. Genotypic variation in rs } 1045642 \text { did not } \\
\text { influence the efficacy of etanercept in Han Chinese patients with } \\
\text { ankylosing spondylitis }\end{array}$ & Yan et al. (2017) [24] \\
\hline Han Chinese & 236 & $58(24.58)$ & $47(19.91)$ & $131(55.51)$ & $\begin{array}{l}\text { Different from the finding of this study, the mutant allele frequency } \\
\text { of C } 3435 \mathrm{~T}(65.5 \%) \text { was higher than that of } \mathrm{C} \text { allele. There was } \\
\text { no significant difference in the dose of sufentanil for Han Chinese } \\
\text { patients who suffered pain due to lung cancer }\end{array}$ & Zhao et al. (2019) [25] \\
\hline Taiwanese & 112 & $29(25.89)$ & $52(46.43)$ & $31(27.68)$ & $\begin{array}{l}\text { T allele was found at } 50.9 \% \text {. Both the baseline score of Hamilton } \\
\text { Depression Rating Scale and that of week } 6 \text { in antidepressant } \\
\text { therapy were insignificantly different among the ABCB1 C } 3435 \mathrm{~T} \\
\text { genotypic variance of Taiwanese patients with major depressive } \\
\text { disorder }\end{array}$ & Chang et al. (2015) [26] \\
\hline Japanese & $\begin{array}{l}154 \text { (healthy subjects) } \\
48 \text { (patients with CRC) } \\
47 \text { (patients with } \\
\text { ESCC) }\end{array}$ & $\begin{array}{l}55(35.72) \\
14(29.17) \\
11(23.40)\end{array}$ & $\begin{array}{l}73(47.40) \\
28(58.33) \\
28(59.58)\end{array}$ & $\begin{array}{l}26(16.88) \\
6(12.50) \\
8(17.02)\end{array}$ & $\begin{array}{l}\text { The mutant allele frequency of C3435T was higher than that of } \\
C \text { allele. No significant difference was found in the estimation of } \\
\text { MDR1 haplotype frequency between Japanese healthy subjects } \\
\text { ( } n=154 \text { ) and patients with CRC as well as ESCC }\end{array}$ & Komoto et al. (2006) [27] \\
\hline Turkish & 54 & $19(35.19)$ & $22(40.74)$ & $13(24.07)$ & $\begin{array}{l}\text { T allele was found at } 44.4 \% \text {. The study found that the } \\
\text { distributions of } C C \text { genotype and } C \text { allele in } A B C B 1 C 3435 T \\
\text { were significantly different between Turkish patients with major } \\
\text { depressive disorder and healthy subjects ( } n=70 \text { ). However, } \\
\text { ABCB1 C } 3435 T \text { polymorphism did not influence the clinical } \\
\text { response to citalopram }\end{array}$ & Ozbey et al. (2014) [28] \\
\hline Iranian & $\begin{array}{l}115 \text { ( } 34 \text { patients, } 81 \\
\text { healthy subjects) }\end{array}$ & $24(20.87)$ & $58(50.43)$ & $33(28.70)$ & $\begin{array}{l}\text { Contrary to our findings, the mutant allele frequency of C } 3435 \mathrm{~T} \\
(53.9 \%) \text { was higher than that of } \mathrm{C} \text { allele. The haplotype frequency } \\
\text { estimation (including } A B C B 1 \mathrm{C} 3435 \mathrm{~T} \text { ) did not indicate any } \\
\text { significant difference between patients and the control group }\end{array}$ & Hosseini et al. (2018) [29] \\
\hline Egyptian & $\begin{array}{l}220 \text { ( } 120 \text { patients, } 110 \\
\text { healthy subjects as } \\
\text { control group) }\end{array}$ & $26(11.82)$ & $141(64.09)$ & $53(24.09)$ & $\begin{array}{l}\text { T allele frequency was at } 56.1 \% \text {. The CT genotype in MDR1 gene } \\
\text { C3435T correlated with the poor clinical outcomes in Egyptian } \\
\text { pediatric patients with acute lymphoblastic leukemia }\end{array}$ & Talaat et al. (2018) [30] \\
\hline South Indian & 460 patients & $24(5.22)$ & $245(53.26)$ & $191(41.52)$ & $\begin{array}{l}\text { Different from our findings, the mutant allele frequency of C } 3435 \mathrm{~T} \\
(68.2 \%) \text { was higher than that of } \mathrm{C} \text { allele. This cohort study found } \\
\text { that the variants in } A B C B 1 \text { (including } \mathrm{C} 3435 \mathrm{~T} \text { ) did not correlate } \\
\text { with antiepileptic drug resistance. However, } A B C B 1 \mathrm{C} 3435 \mathrm{~T} \\
\text { polymorphism was associated with the risk of developing epilepsy } \\
\text { in patients with mesial temporal lobe epilepsy with hippocampal } \\
\text { sclerosis }\end{array}$ & Balan et al. (2014) [31] \\
\hline $\begin{array}{l}\text { Roman and } \\
\text { Hungarian }\end{array}$ & $\begin{array}{l}465 ; 503 \text { healthy } \\
\text { subjects }\end{array}$ & $\begin{array}{l}\text { Roman } 124 \\
(26.67) \\
\text { Hungarian } \\
112(22.27)\end{array}$ & $\begin{array}{l}\text { Roman } 234 \\
(50.32) \\
\text { Hungarian } \\
252(50.10)\end{array}$ & $\begin{array}{l}\text { Roman } 107 \\
(23.01) \\
\text { Hungarian } 139 \\
(27.63)\end{array}$ & $\begin{array}{l}\text { There was a significant difference in the T allele frequency of } \\
\text { MDR1 between Roman population }(48.2 \%) \text { and Hungarian } \\
\text { people }(52.7 \%) \text {. The T allele frequency in our study was found to } \\
\text { be comparable with that of Roman population }\end{array}$ & Sipeky et al. (2011) [32] \\
\hline Polish & $\begin{array}{l}171 \text { ( } 71 \text { patients, } 100 \\
\text { healthy subjects) }\end{array}$ & $37(21.64)$ & $76(44.44)$ & $58(33.92)$ & $\begin{array}{l}\text { T allele distribution was at } 56.1 \% \text {. } 1236 \mathrm{~T}-2677 \mathrm{G}-3435 \mathrm{~T} \text { haplotype } \\
\text { could provide a protective effect against bullous pemphigoid }\end{array}$ & $\begin{array}{l}\text { Rychlik-Sych et al. } \\
\text { (2018) [33] }\end{array}$ \\
\hline Polish & 90 & $15(16.67)$ & $43(47.78)$ & $32(35.55)$ & $\begin{array}{l}\text { T allele distribution ( } 59.4 \%) \text { was higher than that of } \mathrm{C} \text { allele. } \\
\text { C3435T polymorphism in } A B C B 1 \text { gene strongly correlated with } \\
\text { predisposition to depression, severity of depression symptoms, } \\
\text { and effectiveness of antidepressants }\end{array}$ & Jeleń et al. (2015) [34] \\
\hline Romanian & 74 & $14(18.92)$ & $37(50.00)$ & $23(31.08)$ & $\begin{array}{l}\text { T allele frequency was } 56.1 \% \text {. ABCB1 C3435T polymorphism } \\
\text { did not influence the plasma concentration of valproate or dose } \\
\text { adjustment with reference to valproate concentration among } \\
\text { Romanian patients with epilepsy }\end{array}$ & Sabin et al. (2016) [35] \\
\hline Croatian & 60 & $16(26.67)$ & $31(51.66)$ & $13(21.67)$ & $\begin{array}{l}\text { Similar to our finding, this study also found a lower T allele } \\
\text { frequency }(47.5 \%) \text { as opposed to that of } C \text { allele. C } 3435 T \\
\text { polymorphisms in } A B C B 1 \text { gene influenced the concentration ratio } \\
\text { of phenobarbital in serum/cerebrospinal fluid among Croatian } \\
\text { patients with idiopathic primary generalized epilepsy who } \\
\text { received phenobarbital monotherapy }\end{array}$ & Basic et al. (2008) [36] \\
\hline
\end{tabular}


Table 2: (Continued)

\begin{tabular}{|c|c|c|c|c|c|c|}
\hline \multirow[t]{2}{*}{ Population/ethnicity } & \multirow[t]{2}{*}{ Sample size } & \multicolumn{3}{|c|}{ Genotype frequencies n (\%) } & \multirow[t]{2}{*}{ Findings } & \multirow[t]{2}{*}{ References } \\
\hline & & $\mathrm{CC}$ & CT & TT & & \\
\hline \multicolumn{7}{|l|}{ Original article } \\
\hline Spanish & 74 & $21(28.38)$ & $33(44.59)$ & $20(27.03)$ & $\begin{array}{l}\text { T allele (49.3\%) was found to be less than C allele in ABCB1 } \\
\text { C3435T. In addition to the risk of developing hyperbilirubinemia, } \\
\text { the plasma concentration of atazanavir was significantly higher in } \\
\text { HIV-infected patients with CC genotype compared to those with } \\
\text { CT or TT variants }\end{array}$ & Nóvoa et al. (2006) [37] \\
\hline \multirow[t]{2}{*}{ Portuguese } & 160 & $56(35.00)$ & $73(45.62)$ & $31(19.38)$ & $\begin{array}{l}\text { T allele in } A B C B 1 \text { C } 3435 \mathrm{~T} \text { was found at } 42.2 \% \text {. This allele } \\
\text { provided protection against major depression in male subjects }\end{array}$ & Santos et al. (2013) [38] \\
\hline & 937 & $260(27.75)$ & $482(51.44)$ & $195(20.81)$ & $\begin{array}{l}\text { T allele ( } 46.5 \% \text { ) was lower than C allele in } A B C B 1 \text { C3435T. } \\
\text { Patients with minor T allele in } A B C B 1 \text { rs } 1045642 \text { achieved } \\
\text { better clinical outcomes as opposed to the CC genotype group } \\
\text { undergoing gemtuzumab ozogamicin (GO) therapy and risk } \\
\text { of relapse. Consistent results were also obtained when the } \\
\text { genotype group was compared by GO and No-GO arms }\end{array}$ & $\begin{array}{l}\text { Children's Oncology } \\
\text { Group AAML0531 Trial } \\
\text { Rafiee et al. (2019) [39] }\end{array}$ \\
\hline Caucasian & 40 & $15(37.50)$ & $18(45.00)$ & $7(17.50)$ & $\begin{array}{l}\text { T allele distribution was found at } 40.0 \% \text {. Polymorphism of } \\
\text { rs } 1045642 \text { in } A B C B 1 \text { gene significantly correlated with increased } \\
\text { blood pressure in } 1 \text { year after patients had a kidney transplant }\end{array}$ & Bouatou et al. (2018) [40] \\
\hline $\begin{array}{l}\text { Caucasian } \\
4 \text { case-control studies }\end{array}$ & $\begin{array}{l}395 \text { patients dan } 418 \\
\text { healthy subjects as } \\
\text { control group }\end{array}$ & $207(25.46)$ & $403(49.57)$ & $203(24.97)$ & $\begin{array}{l}\text { T allele in } A B C B 1 \text { C } 3435 T \text { was found at } 49.8 \% \text {. MDR1 C>T } \\
\text { polymorphism was not associated with the risk of multiple } \\
\text { myeloma }\end{array}$ & Razi et al. (2018) [41] \\
\hline Caucasian & 100 & $17(17)$ & $53(53)$ & $30(30)$ & $\begin{array}{l}\text { T allele (56.5\%) was found higher compared to C allele in ABCB1 } \\
\text { C3435T. The highest antihypertensive effect of amlodipine with } \\
\text { minimum incidence of reactions was found in the Caucasian } \\
\text { patient group with Stage I-II hypertension and TT genotype }\end{array}$ & Sychev et al. (2018) [42] \\
\hline Russian & 60 & $15(25)$ & $29(48.33)$ & $16(26.67)$ & $\begin{array}{l}\text { T allele distribution in } A B C B 1 \text { C } 3435 T \text { was } 50.8 \% \text {. Polymorphism } \\
\text { of rs } 1045642 \text { in } A B C B 1 \text { gene made a major contribution to the } \\
\text { safety of dabigatran in patients undergoing knee surgery }\end{array}$ & Sychev et al. (2018) [43] \\
\hline Japanese & 233 & $73(31.33)$ & $160(68.67)$ & & & Hattori et al. (2018) [44] \\
\hline Angolan & 101 & $77(76.24)$ & $16(15.84)$ & $8(7.92)$ & $\begin{array}{l}\text { T allele distribution was at } 15.8 \% \text {. ABCB1 c. } 3435 \mathrm{C}>\mathrm{T} \text { drug } \\
\text { transporter influenced the clinical outcomes of artemether- } \\
\text { lumefantrine in malaria patients without complications }\end{array}$ & Kiaco et al. (2017) [45] \\
\hline Polish & 196 & $46(23.47)$ & $83(42.35)$ & $67(34.18)$ & $\begin{array}{l}\text { T allele (55.4\%) was higher than C allele in } A B C B 1 \text { C } 3435 T \text {. } \\
\text { ABCB1 C3435T polymorphism was not a major factor in } \\
\text { susceptibility to peptic ulcer but a risk factor in developing } \\
\text { Helicobacter pylori infection in male patients }\end{array}$ & $\begin{array}{l}\text { Sałagacka et al. } \\
\text { (2011) [46] }\end{array}$ \\
\hline Spanish & 473 & $138(29.18)$ & $243(51.37)$ & $92(19.45)$ & $\begin{array}{l}\text { Similar to our study, this research also found T allele distribution } \\
(45.1 \%) \text { that was lower than that of } C \text { allele. } A B C B 1 \text { C } 3435 T \\
\text { polymorphism influenced the elimination of several antipsychotics } \\
\text { and antidepressants }\end{array}$ & $\begin{array}{l}\text { Saiz Rodríguez et al. } \\
\text { (2018) [47] }\end{array}$ \\
\hline \multicolumn{7}{|c|}{ Systematic review/meta-analysis } \\
\hline \multirow{2}{*}{\multicolumn{3}{|c|}{$\begin{array}{l}\text { Category } \\
\text { Meta-analysis in studies of Caucasian and Asian }\end{array}$}} & Sample & & Findings & References \\
\hline & & & 8604 & & $\begin{array}{l}\text { ABCB1 C3435T polymorphism was a genetic marker for } \\
\text { antiepileptic drug resistance associated with Caucasian } \\
\text { population but not among Asian people }\end{array}$ & Li et al. (2015) [48] \\
\hline \multicolumn{3}{|c|}{ Systematic review and meta-analysis of 13 studies } & 736 & & $\begin{array}{l}\text { TT genotype in } A B C B 1 \text { C3435T played a role in refractory } \\
\text { epilepsy }\end{array}$ & Chouchi et al. (2017) [49] \\
\hline \multicolumn{3}{|c|}{ Moroccan case-control study and meta-analysis } & \multicolumn{2}{|c|}{$\begin{array}{l}\text { Various populations in the } \\
\text { meta-analysis; } 60 \text { patients } \\
\text { and } 68 \text { healthy women in the } \\
\text { case-control study }\end{array}$} & $\begin{array}{l}\text { The implication of C } 3435 \mathrm{~T} \text { variant on the risk of breast cancer } \\
\text { was ethnicity-dependent. The case-control study found no } \\
\text { evidence that such polymorphism played an important role in } \\
\text { susceptibility to breast cancer }\end{array}$ & Tazzite et al. (2016) [50] \\
\hline \multicolumn{3}{|c|}{ Meta-analysis of 17 studies } & \multicolumn{2}{|c|}{$\begin{array}{l}2431 \text { cases and } 3028 \\
\text { controls from various } \\
\text { countries and ethnic groups }\end{array}$} & $\begin{array}{l}\text { C3435T polymorphism in } A B C B 1 \text { gene was associated with an } \\
\text { increased risk of leukemia }\end{array}$ & Ma et al. (2015) [51] \\
\hline \multicolumn{3}{|c|}{ Meta-analysis of 12 studies } & \multicolumn{2}{|c|}{ Varied ethnic groups } & $\begin{array}{l}\text { C3435T polymorphism in } A B C B 1 \text { gene could become a risk } \\
\text { factor in major adverse cardiovascular events among patients } \\
\text { who received clopidogrel, and TT homozygote had a lower } \\
\text { hemorrhage risk than CC homozygote }\end{array}$ & Su et al. (2012) [52] \\
\hline
\end{tabular}

the pharmacokinetics of antiviral atazanavir and the clinical outcomes of artemether-lumefantrine antimalarial regimen [37], [45] as well as the chemotherapy clinical outcomes in pediatric patients with leukemia [30], [39]. Furthermore, C3435T rs1045642 polymorphism has even been proven to correlate significantly with amlodipine efficacy and safety, patients' blood pressure after kidney transplantation, and the safety of dabigatran as a thrombin inhibitor [40], [42], [43]. Not only associated with pharmacogenomics because of their function as part of cellular defense mechanism, but C3435T polymorphism also has a significant clinical correlation as a predisposition to depressive disorders [28], [34], [38]. A similar finding was also found in a study of haplotype involving such polymorphism with the risk of colorectal and esophageal cancer and in a systematic review and meta-analysis regarding the genetic susceptibility to multiple myeloma [27], [41].
These relatively high frequencies of C3435T mutant allele among the Javanese-Indonesian population require further studies. This is in accordance with the lacking involvement of the Indonesian population in new drug development for a drug selection approach, availability of more appropriate therapeutic doses, and health promotion strategies to prevent cancer among vulnerable subject groups.

\section{Conclusion}

The findings in the study of $A B C B 1$ rs1045642 $\mathrm{C}>\mathrm{T}$ allele frequencies among healthy volunteers of Javanese-Indonesian ethnic group become a novelty 
in the preliminary study of CBZ pharmacogenetics study that has never been conducted. The results indicate that the frequency of subjects with $\mathrm{T}$ allele in $A B C B 1 \mathrm{C} 3435 \mathrm{~T}$ gene was lower than that with $\mathrm{C}$ allele, reaching $47 \%$. Further research is recommended to analyze the correlation between such polymorphism and their implications for pharmacokinetic variability as well as $\mathrm{CBZ}$ resistance.

\section{Acknowledgment}

The authors thank the Ministry of Research, Technology, and Higher Education of the Republic of Indonesia and the Directorate of Research and Community Services of Universitas Islam Indonesia for funding the research.

\section{References}

1. Löscher W, Klotz U, Zimprich F, Schmidt D. The clinical impact of pharmacogenetics on the treatment of epilepsy. Epilepsia. 2009;50(1):1-23. https://doi. org/10.1111/j.1528-1167.2008.01716.x

PMid:18627414

2. PERDOSSI. Pedoman Tatalaksana Epilepsi. $5^{\text {th }}$ ed. Surabaya: Airlangga Unversity Press; 2014.

3. Kemenkes RI. Formularium Nasional. Jakarta: Kementrian Kesehatan Republik Indonesia; 2017.

4. Schinkel AH, Jonker JW. Mammalian drug efflux transporters of the ATP binding cassette (ABC) family: An overview. Adv Drug Deliv Rev. 2003;55(1):3-29.

\section{PMid:12535572}

5. FDA. Information for Healthcare Professionals: Dangerous or Even Fatal Skin Reactions Carbamazepine (Marketed as Carbatrol, Equetro, Tegretol, and Generics). Adv FDA's Saf Program Mark Drugs; 2012. Available from: https://www.fda.gov/drugs/drugsafety/ postmarketdrugsafetyinformationforpatientsandproviders/ ucm124718.htm. [Last accessed on 2018 Jan 22].

6. Yuliwulandari $\mathrm{R}$, Kashiwase $\mathrm{K}$, Nakajima $\mathrm{H}$, Uddin $\mathrm{J}$, Susmiarsih TP, Sofro AS, et al. Polymorphisms of HLA genes in Western Javanese (Indonesia): Close affinities to Southeast Asian populations. Tissue Antigens 2009;73(1):46-53. https:// doi.org/10.1111/j.1399-0039.2008.01178.x PMid:19140832

7. Kwan P, Brodie MJ. Early identification of refractory epilepsy. N Engl J Med. 2000;342(5):314-9. https://doi.org/10.1056/ NEJM200002033420503 PMid:10660394

8. Sisodiya SM, Goldstein DB. Drug resistance in epilepsy: More twists in the tale. Epilepsia. 2007;48(12):2369-70. https://doi. org/10.1111/j.1528-1167.2007.01260_1.x

PMid:18088268

9. Kwan P, Brodie MJ. Effectiveness of first antiepileptic drug. Epilepsia. 2001;42(10):1255-60. https://doi. org/10.1046/j.1528-1157.2001.04501.x

PMid:11737159
10. Tanigawara Y. Role of P-glycoprotein in drug disposition. Ther Drug Monit. 2000;22(1):137-40. https://doi. org/10.1097/00007691-200002000-00029 PMid: 10688277

11. Seo T, Ishitsu T, Ueda N, Nakada N, Yurube $\mathrm{K}$, Ueda $\mathrm{K}$, et al $A B C B 1$ polymorphisms influence the response to antiepileptic drugs in Japanese epilepsy patients. Pharmacogenomics. 2006;7(4):551-61. https://doi.org/10.2217/14622416.7.4.551 PMid: 16753003

12. Siddiqui $A$, Kerb $R$, Weale $M E$, Brinkmann $U$, Smith $A$ Goldstein DB, et al. Association of multidrug resistance in epilepsy with a polymorphism in the drug-transporter gene ABCB1. N Engl J Med. 2003;348(15):1442-8. https://doi. org/10.1056/NEJMoa021986

PMid: 12686700

13. Meng H, Guo G, Ren J, Zhou H, Ge Y, Guo Y. Effects of ABCB1 polymorphisms on plasma carbamazepine concentrations and pharmacoresistance in Chinese patients with epilepsy. Epilepsy Behav. 2011;21(1):27-30. https://doi.org/10.1016/j. yebeh.2011.02.015.

PMid:21493161

14. Ozgon GO, Bebek N, Gul G, Cine N. Association of MDR1 (C3435T) polymorphism and resistance to carbamazepine in epileptic patients from Turkey. Eur Neurol. 2008;59(1-2):67-70. https://doi.org/10.1159/000109264

PMid: 17917461

15. Holsinger KE. Hardy Weinberg law. In: Encyclopedia of Genetics. Amsterdam, Netherlands: Elsevier; 2001. p. 912-4. https://doi.org/10.1006/rwgn.2001.0585.

16. Rogers AJ, Weiss ST. Epidemiologic and population genetic studies. In: Robertson D, Williams GH, editors. Clinical and Translation Science: Principles of Human Research. United Kingdom: Elsevier; 2017. p. 313-26. https://doi.org/10.1016/ b978-0-12-802101-9.00017-x

17. Bebawy M, Chetty $M$. Gender differences in p-glycoprotein expression and function: Effects on drug disposition and outcome. Curr Drug Metab. 2009;10(4):322-8. https://doi. org/10.2174/138920009788498996

PMid: 19519340

18. Leschziner GD, Andrew T, Pirmohamed M, Johnson MR. $A B C B 1$ genotype and PGP expression, function and therapeutic drug response: A critical review and recommendations for future research. Pharmacogenomics J. 2007;7(3):154-79. https://doi. org/10.1038/sj.tpj.6500413

PMid:16969364

19. Romiti N, Tramonti G, Donati A, Chieli E. Effects of grapefruit juice on the multidrug transporter P-glycoprotein in the human proximal tubular cell line HK-2. Life Sci. 2004;76(3):293-302. https://doi.org/10.1016/j.lfs.2004.06.015 PMid:15531381

20. Marino S, Birnbaum A, Leppik I, Conway J, Musib L, Brundage R, et al. Steady-state carbamazepine pharmacokinetics following oral and stable-labeled intravenous administration in epilepsy patients: Effect of race and sex. Clin Pharmacol Ther. 2012;91(3):483-8. https://doi.org/10.1038/clpt.2011.251 PMid:22278332

21. Zhu X, Yun W, Sun X, Qiu F, Zhao L, Guo Y. Effects of major transporter and metabolizing enzyme gene polymorphisms on carbamazepine metabolism in Chinese patients with epilepsy. Pharmacogenomics. 2014;15(15):1867-79. https://doi. org/10.2217/pgs.14.142

PMid:25495409

22. Gong XD, Wang JY, Liu F, Yuan HH, Zhang WY, Guo YH, et al. Gene polymorphisms of OPRM1 A118G and ABCB1 C3435T may influence opioid requirements in chinese patients with 
cancer pain. Asian Pac J Cancer Prev. 2013;14(5):2937-43. PMid:23803057

23. Shan $X X$, Qiu $Y$, Xie WW, Wu RR, Yu Y, Wu HS, et al. ABCB1 gene is associated with clinical response to SNRIs in a local chinese han population. Front Pharmacol. 2019;10:761. https:// doi.org/10.3389/fphar.2019.00761

PMid:31333472

24. Yan RJ, Lou TT, Wu YF, Chen WS. Single nucleotide polymorphisms of ABCB1 gene and response to etanercept treatment in patients with ankylosing spondylitis in a Chinese Han population. Medicine (Baltimore). 2017;96(5):e5929. https://doi.org/10.1097/MD.0000000000005929 PMid:28151874

25. Zhao Z, Lv B, Zhao X, Zhang Y. Effects of OPRM1 and ABCB1 gene polymorphisms on the analgesic effect and dose of sufentanil after thoracoscopic-assisted radical resection of lung cancer. Biosci Rep. 2019;39(1):BSR20181211. https://doi. org/10.1042/BSR20181211

\section{PMid:30455395}

26. Chang $\mathrm{HH}$, Chou $\mathrm{CH}$, Yang YK, Lee IH, Chen PS. Association between $\mathrm{ABCB} 1$ polymorphisms and antidepressant treatment response in Taiwanese major depressive patients. Clin Psychopharmacol Neurosci. 2015;13(3):250-5. https://doi. org/10.9758/cpn.2015.13.3.250

PMid:26598582

27. Komoto C, Nakamura T, Sakaeda T, Kroetz DL, Yamada T, Omatsu $\mathrm{H}$, et al. MDR1 haplotype frequencies in Japanese and Caucasian, and in Japanese patients with colorectal cancer and esophageal cancer. Drug Metab Pharmacokinet. 2006;21(2):126-32.

PMid: 16702732

28. Ozbey G, Yucel B, Taycan SE, Kan D, Bodur NE, Arslan T, et al. ABCB1 C3435T polymorphism is associated with susceptibility to major depression, but not with a clinical response to citalopram in a Turkish population. Pharmacol Rep. 2014;66(2):235-8. https://doi.org/10.1016/j.pharep.2013.09.004 PMid:24911075

29. Hosseini M, Ebrahimi A, Houshmand M, Zainali $S$, Tonekaboni SH, Moghaddasi M. SCN1A and ABCB1 polymorphisms in epilepsy. Arch Neurosci. 2018;5(1):e59383. https://doi.org/10.5812/archneurosci.59383

30. Talaat RM, El-Kelliny MK, El-Akhras BA, Bakry RM, Riad KF, Guirgis AA. Association of C3435T, C1236T and C4125A polymorphisms of the MDR-1 gene in Egyptian children with acute lymphoblastic leukaemia. Asian Pac J Cancer Prev. 2018;19(9):2535-43. https://doi.org/10.22034/ APJCP.2018.19.9.2535

PMid:30256048

31. Balan S, Bharathan SP, Vellichiramal NN, Sathyan S, Joseph V, Radhakrishnan K, et al. Genetic association analysis of ATP binding cassette protein family reveals a novel association of ABCB1 genetic variants with epilepsy risk, but not with drug-resistance. PLoS One. 2014;9(2):e89253. https://doi. org/10.1371/journal.pone.0089253 PMid:24586633

32. Sipeky C, Csongei V, Jaromi L, Safrany E, Maasz A, Takacs I, et al. Genetic variability and haplotype profile of MDR1 (ABCB1) in Roma and Hungarian population samples with a review of the literature. Drug Metab Pharmacokinet. 2011;26(2):206-15. PMid:21178299

33. Rychlik-Sych M, Barańska M, Dudarewicz M, Skrętkowicz J, Żebrowska A, Woźniacka A, et al. Haplotypes of ABCB1 1236C >T (rs1128503), 2677G >T/A (rs2032582), and $3435 \mathrm{C}>\mathrm{T}$ ( $\mathrm{rs} 1045642)$ in patients with bullous pemphigoid. Arch Dermatol Res. 2018;310(6):515-22. https://doi.org/10.1007/ s00403-018-1842-8
PMid:29948283

34. Jeleń AM, Sałagacka A, Żebrowska MK, Mirowski M, Talarowska M, Gałecki P, et al. The influence of C3435T polymorphism of the ABCB1 gene on genetic susceptibility to depression and treatment response in polish population preliminary report. Int J Med Sci 2015;12(12):974-9. https://doi. org/10.7150/ijms.13119

PMid:26664259

35. Sabin O, Pop R, Trifa A, Buzoianu AD. The Influence of CYP2C9, CYP2C19 and ABCB1 Polymorphisms on the Plasma Concentrations of Valproic Acid in Epileptic Patients. Vol. 8; 2016. p. 5.

36. Basic S, Hajnsek S, Bozina N, Filipcic I, Sporis D, Mislov D, et al. The influence of C3435T polymorphism of ABCB1 gene on penetration of phenobarbital across the blood brain barrier in patients with generalized epilepsy. 2008;17(6):524-30. https:// doi.org/10.1016/j.seizure.2008.01.003

PMid:18329296

37. Nóvoa SR, Barreiro $P$, Rendón A, Barrios A, Corral A, Jiménez-Nacher I, et al. Plasma levels of atazanavir and the risk of hyperbilirubinemia are predicted by the $3435 \mathrm{C} \rightarrow T$ polymorphism at the multidrug resistance gene 1 . Clin Infect Dis. 2006;42(2):291-5. https://doi.org/10.1086/499056 PMid: 16355344

38. Santos M, Carvalho S, Lima L, Nogueira A, Assis J, MotaPereira J, et al. Common genetic polymorphisms in the ABCB1 gene are associated with risk of major depressive disorder in male portuguese individuals. Genet Test Mol Biomark. 2013;18(1):12-9. https://doi.org/10.1089/gtmb.2013.0197 PMid:24200053

39. Rafiee R, Chauhan L, Alonzo TA, Wang YC, Elmasry A, Loken MR, et al. ABCB1 SNP predicts outcome in patients with acute myeloid leukemia treated with gemtuzumab ozogamicin: A report from children's oncology group AAML0531 Trial. Blood Cancer J. 2019;9:1127. https://doi.org/10.1038/ s41408-019-0211-y

40. Bouatou Y, Stenz L, Ponte B, Ferrari S, Paoloni-Giacobino A, Hadaya K. Recipient rs1045642 polymorphism is associated with office blood pressure at 1-year post kidney transplantation: A single center pharmacogenetic cohort pilot study. Front Pharmacol. 2018;9:184. https://doi.org/10.3389/ fphar.2018.00184

PMid:29556197

41. Razi B, Sarab GA, Omidkhoda A, Alizadeh S. Multidrug resistance 1 (MDR1/ABCB1) gene polymorphism (rs1045642 C> T) and susceptibility to multiple myeloma: A systematic review and meta-analysis. Hematology. 2018;23(8):456-62. https://doi.org/10.1080/10245332.2018.1443897

PMid:29495954

42. Sychev D, Shikh N, Morozova T, Grishina E, Ryzhikova K Malova E. Effects of ABCB1 rs1045642 polymorphisms on the efficacy and safety of amlodipine therapy in Caucasian patients with stage I-II hypertension. Pharmacogenomics Pers Med. 2018;11:157-65. https://doi.org/10.2147/PGPM.S158401 PMid:30288082

43. Sychev DA, Levanov AN, Shelekhova TV, Bochkov PO, Denisenko NP, Ryzhikova KA, et al. The impact of ABCB1 (rs1045642 and rs4148738) and CES1 (rs2244613) gene polymorphisms on dabigatran equilibrium peak concentration in patients after total knee arthroplasty. Pharmacogenomics Pers Med. 2018;11:127-37. https://doi.org/10.2147/PGPM.S169277 PMid:30100750

44. Hattori S, Suda A, Kishida I, Miyauchi M, Shiraishi $Y$, Fujibayashi M, et al. Effects of ABCB1 gene polymorphisms on autonomic nervous system activity during atypical antipsychotic treatment in schizophrenia. BMC Psychiatry. 2018;18(1):231. 
https://doi.org/10.1186/s12888-018-1817-5

PMid:30016952

45. Kiaco K, Rodrigues AS, do Rosário V, Gil JP, Lopes D. The drug transporter $\mathrm{ABCB} 1$ c.3435C $>\mathrm{T}$ SNP influences artemetherlumefantrine treatment outcome. Malar J. 2017;16(1):383. https://doi.org/10.1186/s12936-017-2006-6 PMid:28934955

46. Sałagacka A, Bartczak $M$, Zebrowska $M$, Jażdżyk $M$, Balcerczak M, Janiuk R, et al. C3435T polymorphism of the ABCB1 gene: Impact on genetic susceptibility to peptic ulcers. Pharmacol Rep. 2011;63(4):992-8. https://doi.org/10.1016/ s1734-1140(11)70615-6

PMid:22001987

47. Saiz-Rodríguez M, Belmonte C, Román M, Ochoa D, JiangZheng C, Koller D, et al. Effect of ABCB1 C3435T polymorphism on pharmacokinetics of antipsychotics and antidepressants. Basic Clin Pharmacol Toxicol. 2018;123(4):474-85. https://doi. org/10.1111/bcpt.13031

PMid:29723928

48. Li S, Liu Y, Wang Q. ABCB1 gene C3435T polymorphism and drug resistance in epilepsy: Evidence based on 8604 subjects. Med Sci. 2015;21:861-8. https://doi.org/10.12659/MSM.894023 PMid:25799371

49. Chouchi M, Kaabachi W, Klaa H, Tizaoui K, Turki IB, Hila L. Relationship between ABCB1 3435TT genotype and antiepileptic drugs resistance in epilepsy: Updated systematic review and meta-analysis. BMC Neurol. 2017;17(1):32. https:// doi.org/10.1186/s12883-017-0801-x

PMid:28202008

50. Tazzite A, Kassogue Y, Diakité B, Jouhadi H, Dehbi H, Benider A et al. Association between ABCB1 C3435T polymorphism and breast cancer risk: A Moroccan case-control study and metaanalysis. BMC Genet. 2016;17(1):126. https://doi.org/10.1186/ s12863-016-0434-x

\section{PMid:27580695}

51. Ma L, Ruan L, Liu H, Yang H, Feng Y. ABCB1 C3435T polymorphism is associated with leukemia susceptibility: Evidence from a meta-analysis. Onco Targets Ther. 2015;8:1009-15. https://doi.org/10.2147/OTT.S82144 PMid:25999734

52. Su J, Xu J, Li X, Zhang $H$, Hu J, Fang R, et al. ABCB1 C3435T polymorphism and response to clopidogrel treatment in coronary artery disease (CAD) patients: A meta-analysis. PLoS One. 2012;7(10):e46366. https://doi.org/10.1371/journal. pone.0046366

PMid:23056288

53. Remy S, Beck H. Molecular and cellular mechanisms of pharmacoresistance in epilepsy. Brain J Neurol. 2006;129(Pt 1):18-35. https://doi.org/10.1093/brain/awh682 PMid:16317026 